\title{
An International Graduate Student's ESL Learning Experience Beyond the Classroom
}

International graduate students are coming in ever-growing numbers to English-speaking countries. Educators have long believed that the successful English-learning experience of these students in their home countries will naturally lead to success in their academic studies and social life abroad. However, this may be not true. Using my English-learning experiences as a basis for research, in this article I explore the role of target-language improvement in adaptation to new environments. Based on a supportive sociocultural theory of second-language acquisition, the article provides recommendations for assisting international graduate students, especially those from East Asia, to enhance their academic performance and quality of life in Canada.

Les étudiants internationaux aux études supérieures arrivent en nombres toujours croissants aux pays de langue anglaise. Les enseignants ont longtemps cru que l'apprentissage réussi de l'anglais par ces étudiants dans leurs pays d'origine mènerait naturellement à leur réussite académique et sociale à l'étranger. Cela $n^{\prime} e s t$ pas forcément vrai, par contre. Fondant ma recherche sur mes expériences en apprentissage de l'anglais, j'étudie le rôle que joue l'amélioration de la langue cible dans l'adaptation à un nouveau milieu. Appuyé par une théorie socioculturelle de soutien portant sur l'acquisition d'une langue seconde, l'article offre des recommandations aux étudiants internationaux aux études supérieures, notamment ceux de l'Asie orientale, visant l'amélioration de leur rendement académique et leur qualité de vie au Canada.

Nowadays the population of international students in the universities of English-speaking countries is increasing (Freed, 1998; Kodama, 2007; Perrucci \& Hu, 1995; Trice, 2004; Umakoshi, 1997). People tend to believe that English-as-a-second-language (ESL) students who study and live in the target-language country can develop their English proficiency naturally (Coleman, 1997; Freed). International graduate students who have had extensive and successful English-learning experiences in their home countries in particular often believe that they can succeed in both academic study and social life in the new environment (Perrucci \& Hu). However, this may not always be true. Some studies show that international students' exposure to native English-speakers outside the classroom is so limited that it is not sufficient for them to improve their English, especially in 
oral communication (Ranta, 2007; Spurling, 2007; Zimmerman, 1995). This may be due to the graduate students' busy schedule, language proficiency, value system, and/or the degree to which they experience culture shock (Kodama; Perrucci \& Hu; Ranta; Trice). East Asian students usually face language challenges in English-speaking countries because of the large gap between their native language and culture and those of the target-language country (Trice; Walter, 2004). International graduate students need to develop effective learning strategies to improve their English in order to survive and thrive in their new language environment (Kodama).

However, little research has been done to study the language-learning experiences of international graduate students. It would be beneficial to hear these students' voices in order to gain a better understanding of their English-language-learning experiences and to help support their experiences while they study abroad. What kinds of language-learning experiences outside the classroom do international students require in order to develop their English proficiency? How do international students interact with native English-speakers? What kinds of support do international students require for successful transition to their new environment?

To bridge the gap, I present my own English-learning experiences in Canada from the perspective of an international graduate student. In this article, I first discuss the main barriers to improving my English proficiency that I encountered. Then a literature review guides my discovery of the sociocultural theory of second-language acquisition (SLA), which plays an important role in facilitating language-learning. Based on this review, I discuss the strategies that I have applied to improve my English outside the classroom since coming to Canada. In examining my learning experiences, I reflect on autonomous language-learning as a successful strategy that has enhanced my academic achievements as well as my quality of life in Canada. In the conclusion, I provide recommendations on how international graduate students, particularly those from East Asia, can succeed in the new environment through improving their English proficiency.

\section{Barriers to Improving My English Proficiency}

When I came to Canada, I met enormous challenges in raising my English proficiency, and these affected both my academic studies and my social life. The factors that influenced my adaptation to the new language and culture environment were culture shock, my language proficiency, my cultural personality, and my earlier learning experiences.

\section{Culture Shock}

According to Brown (2008), culture shock is "anxiety that results from losing all familiar signs and symbols of social intercourse, which people do not carry at the level of conscious awareness" (p. 5). Generally, sources of anxiety 
include language challenges, social isolation, identity confusion, weather and food differences, accommodation, separation from home, role and status change, and a different educational system (Coates, 2004). As a sojourner, I experienced challenges adjusting psychologically and socially to life in the new country. I suffered symptoms of culture shock such as loss of my identity, lack of confidence, longing for my home country and family, and unwillingness to interact with others. This made me feel confused about my new life in Canada, and I asked myself why I had come. I had family and good friends in China where I was well taken care of, and I did not need to cook after 9:00 p.m. when I returned from my classes. In China I had a respectable job as a teacher, and I was popular with my students. I realized that my new identity as an international graduate student in Canada was not as successful or respectable as my identity in China. In this new society, I lost my sense of achievement and comfort. I began to worry about my situation and felt lost, and I chose to keep to myself in my own world and associated mostly with other Chinese graduate students, something Siu (1952) defines as "in-group tendency" (p. 36). This is a typical practice among international students. They choose to maintain contact with people who share the same or similar language and culture, which provides a safe and comfortable environment. I would agree that culture shock is one of the main factors that prevents most international students from seeking to improve their English beyond the classroom.

\section{My Language Proficiency}

The second barrier to improving my English proficiency was my perception of my level of English-language proficiency. I did not anticipate that I would meet such challenges with my English. I thought that I could easily succeed in my studies and new life in Canada. Before I came to Canada, I was confident of my English ability. I was regarded as a successful language-learner by my English teachers. People also saw me as an excellent English teacher with a strong ability to teach English language and culture. I even received an award for excellence in English teaching based on my students' outstanding results on the annual National College Entrance Examination (NCEE) in my school in China. Moreover, when I applied for entry into Canadian universities, I succeeded in both the Test of English as a Foreign Language (TOEFL) and the International English Language Testing System (IELTS) with total scores of 617 and 7.0 respectively. However, the reality of my learning experience in Canada was totally different from my expectations. I remember that during my first three months in Canada, I could not understand what my instructors and classmates were talking about in graduate-level classes. I could not solve the easiest problems in my daily life such as taking the correct buses, asking directions, buying food, and so forth. Comparing myself with my fluent classmates, I thought that I looked stupid in class be- 
cause during discussions I could not express myself clearly in English, even though I had good ideas. Brown (2008) and Kodama (2007) found that international students' weak English-language skills resulted in a number of negative outcomes for their language-learning. For example, self-doubt with the consequence of low self-esteem is a common feeling among international students as they struggle to make themselves understood in the new language community. The lower international students' English proficiency, the less confident they are in interacting with others; thus the more difficult it is to improve their English and adapt to the host culture (Jackson, 2002; Trice, 2004). As a new international graduate student, I felt frustrated with my English. Because of my low self-esteem, I avoided speaking and interacting with other students in class, and this prevented me from getting to know people and making friends. It also affected the development of my oral English skills.

\section{Cultural Personality}

The third barrier to developing my English proficiency was my introverted personality. For second-language learners, this kind of personality plays a negative role in language acquisition. Compared with the extroverted personalities of many Western students, Chinese students tend to be more introverted. Therefore, there are many differences in their behaviors and openness to social activities when they are learning a second language. Language-learners who tend actively to seek out new ideas and experiences seem to be more successful than those who are more introverted (Searle \& Ward, 1990).

Reflecting on myself as a language-learner, I am a Chinese who is strongly influenced by the traditional Confucian values of modesty and implicitness. Therefore, I preferred to observe everything and kept my thoughts to myself. I also liked to listen to other people's conversations rather than to engage actively in conversations. I was particularly hesitant to express other opinions or to argue. This means that I may rather think than speak about what is on my mind. This lack of interpersonal communication skills was not conducive to improving my oral English proficiency, which is one of the reasons that my reading and writing skills until recently were better than my listening and speaking skills. In addition, in this new cultural environment, I tended to seek a comfort zone to protect myself rather than to take the risk of practicing my oral English skills. For example, I would go to places and talk to people with whom I was familiar. I took courses instructed by the same professors in separate terms, and because of this, I lost out on many opportunities to come to know and interact with more people and establish relationships that would have enhanced my oral proficiency in English.

\section{Previous Learning Experiences}

The final barrier to increasing my English proficiency was my earlier learning experience. Because I started learning English in secondary school, all class 
instruction was lecture-based and focused on grammar, translation, and written exams. Even when I studied teaching English as a foreign language in university, the teaching pedagogy emphasized cognitive development and individual endeavors in the process of language-learning. The sociocultural aspect was completely ignored. The goal of both teaching and learning was the individual student's successful performance on language exams. While I was studying English in China, I rose early every morning to practice pronunciation and to read aloud by myself. I memorized lists of vocabulary and did grammar exercises every day, but rarely did I practice speaking English with my classmates in a communicative context. Fortunately, I often earned good grades on exams and acknowledgment from my teachers and classmates for my diligence and perseverance. In this language-learning context, I developed my personal English-learning strategy, for example, working hard at memorizing language rules and vocabulary.

However, when I came to Canada, I found that my earlier "successful" learning experiences did not help me to improve my English proficiency. Although I made every effort to adapt to the new language environment, teachers, and classmates, I still struggled daily with my basic ability to communicate in English. It is interesting that as a graduate student, I could read and write academic papers, but felt that I could not deal with simple aspects of my life. I realized that in Canada I must find another way to improve my oral language.

\section{A Breakthrough in My English-Learning Philosophy}

As I searched for more effective ways to improve my English skills, my studies at the University of Alberta broadened my knowledge and understanding of SLA theories. I learned about two theoretical perspectives in this area: the cognitive and the sociocultural. The former recognizes that learning is a mental process that requires individual effort (Gass \& Selinker, 2008; Krashen, 1982), and the latter emphasizes the significant role of language learners' social relationships in the process of their learning (Johnson, 2004; Lave \& Wenger, 1991; Swain, Kinnear \& Steinman, 2010; Toohey, 1998). The sociocultural theory has been propounded by academics in the field of ESL research in recent years, and many theorists have contributed to its theoretical development. Vygotsky (1978) emphasizes the significance of social relations in human development and points out that languagelearning is socioculturally constructed in the learner's community. Bakhtin (1981) states that "verbal discourse is a social phenomenon" (p. 259). This means that a language-learner learns to speak by taking discourses from "other people's mouths" and "other people's intentions" (p. 294) and later tries out these discourses as appropriate. Anthropologists Lave and Wenger provide examples of how language-learning in a variety of contexts is a matter of social practice. They note that "a community of practice is a set 
of relations among persons, activity, and world over time and in relation with other tangential and overlapping communities of practice" (p. 98). In other words, language-learners' access to interaction with others can be facilitated or hindered by specific practices and power relations between learners and people in the community.

Based on the sociocultural theories above, many studies provide more practical examples of the important role of social interaction in facilitating learners' English proficiency. Through interviews, Suh, Wasansomsithi, Short, and Majid (1999) investigated the out-of-class learning experiences of eight Asian international graduate students enrolled in an ESL program in Indiana University in the United States. In this study, most participants confirmed that in addition to some private leisure activities, interacting with native English speakers was the major out-of-class strategy for enhancing their English proficiency. Derwing, Thomson, and Munro (2006) studied the relationship between English learners' exposure to native English-speakers outside the classroom and their improvement in accent and fluency. They compared 20 Mandarin and 20 Slavic adult immigrants to Canada over a period of 10 months through recording and evaluating their narratives and selfreports. The results showed that Slavic learners made significant progress in gaining English fluency, whereas the Mandarin participants did not. This was because the Slavic participants had significantly sought out more contact with native English-speakers than the Mandarin participants. The study revealed that alternative learning strategies such as out-of-class communication with native English speakers helped to facilitate English improvement in addition to enrollment in an ESL class. Recently, Kodama (2007) reported that Japanese international students who studied in the Visiting Students Certificate Program (VSCP) at the University of Alberta broke language and social barriers to seek out more opportunities to interact with Canadian native English-speakers outside the classroom. Through oral interviews and questionnaire surveys, Kodama found that effective out-of-class learning activities for students' English-language improvement were language exchanges, clubs, church and social events, and volunteer experiences.

The sociocultural theory was for me a breakthrough from the traditional concept of cognitive learning. It persuaded me to reform my earlier English-learning philosophy by exploring new concepts and strategies. My strategy was to cast myself out of the classroom context to practice and improve English in authentic communicative contexts. I believe that learning socially is an effective way to break through language and cultural barriers and to improve oral language skills in particular. Once I had set a clear goal for myself, I began to seek out opportunities to use English in a variety of social contexts. 


\section{Actions to Conduct Out-of-Class English Learning Strategies}

\section{Volunteering}

I have been working as a volunteer teaching Mandarin every Saturday since April in a program organized by the Student Volunteer Campus Community (SVCC) at the university. To me the volunteering opportunity provided a friendly, low-stress, and meaningful opportunity to interact with people. First, I am interested in teaching because I my background is in teaching English as a second language in China. Second, I feel more confident and proud to teach my mother tongue with its culture and history to people who are interested. Third, in a beginner-level class, I must use a great deal of English to teach, explain, and communicate with my students. In my class are 10 native English-speakers aged 22-60. Although some are Canadian-born Chinese, they cannot speak Mandarin and have had no experience of living in China. My task is to teach them to pronounce Pinyin correctly with four tones and to teach them basic Chinese characters in varied communication contexts. During class, I use English to negotiate meaning through explaining, questioning, and clarifying. After class, my students and I often speak in English about Chinese customs, people's hobbies, daily life, traveling, and so forth. When I entered the communication chain, I found that I began to learn their words, sentence patterns, and even how they talked to me through the natural process of social interaction. I benefit from these oral interactions in English with my Mandarin students. Moreover, I feel that I have reclaimed my identity. That is, I have gained the feeling of being a teacher once more. Teaching Mandarin enhances my position in this small community because my "identity is respected" and my Chinese-language "resource is valued" (Norton \& Toohey, 2001, p. 318). The more Mandarin lessons I teach, the more confident and motivated I become. I begin to seek more people with whom to communicate in English out of class. I believe that I will progress further in my oral English skills. I am also encouraged to seek more volunteer opportunities in order to improve my English communication skills in the future.

\section{Working at a Part-Time Job}

Another important action that I took to improve my English was to find a part-time job in a Subway store off campus. Through this job, I learned new vocabulary, especially relating to food. It gave me opportunities to interact with a variety of people who had diverse speaking styles and accents. This was especially helpful to me because there was a wide gap between my basic interpersonal communication skills and my cognitive academic language proficiency (Cummins, 1984). My English-learning experiences in both China and Canada were largely focused on formal and academic English rather than on the emotional and social functions of English. I gained more confi- 
dence and was able to speak louder and without anxiety. I realize that if I am confident and willing to take risks and challenge myself, I will reach my full potential in improving my English proficiency.

\section{Choosing a Home Stay}

Before coming to Canada, I decided to live with a Canadian family rather than in a student residence. I am fortunate to have a pleasant landlady who treats me and my roommate (another Chinese graduate student) as her own children. My relationship with her is not only a business arrangement. She calls us her family and treats us like her children. In my heart, I see her as my Canadian mom who cares about me and gives me emotional support whenever I need it. She asks us about our studies, life, and family; shows us around the city; and travels with us too. Living with her makes me feel at home, which helps me overcome homesickness and reduce culture shock. In addition, I have more opportunities to learn authentic English language and to experience Canadian life, culture, customs, foods, and festivals. For example, my landlady taught us how to make cookies, cakes, salads, and steaks. While cooking I learned many new words from various recipes and ingredients. I have learned many names of flowers and vegetables because every spring we plant them together in her garden. Moreover, my landlady invites her friends and relatives to her parties and introduces them to us. At these parties, I have opportunities to talk with guests about my country, hometown, food, and famous travel spots in China. Unlike other international students who live by themselves or with students of the same ethnic group, I have more opportunities to interact with native English-speakers as well as to learn about local culture and social events.

\section{Making Presentations}

To practice my English, I also sought opportunities to make public presentations. As Nunan (1991) states, "Successful language learners applying their developing language skills outside the classroom can play a crucial role in their second language development" (p. 175). Last term I acted as an international graduate student representative for our department in the International Initiatives Office in the Faculty of Education. At the orientation tour meeting, I gave a talk on Strategies for Making Presentations in Graduate Classes for new graduate students. I also provided suggestions for starting a new life in Canada. Although I had to spend time preparing my speech, I valued the opportunity to practice my English and to help others at the same time.

Last winter I also joined Toastmasters International on the recommendation of my landlady. It is a great organization for improving one's communication, public speaking, and leadership skills. I learned how to manage conversations, change subjects, control my speaking rate, and more. In my presenta- 
tions, I have presented topics on the Chinese New Year (the Spring Festival), the Chinese Zodiac, and specific customs for Chinese festivals. Members of our club are friendly and always encourage me to speak more in public and help me with my pronunciation and grammar. I have also made some friends and have had more opportunities to learn more English and more about Canadian culture.

\section{Participating in Leisure Activities}

As a language-learner, I know that I can learn English at any time and in any place such as when I participate in leisure activities. On weekends and holidays, I like to watch television, listen to English-language songs, and watch English-language movies online or at the cinema. I also enjoy attending live theater at the Timms Centre for the Arts. In addition, I have taken courses such as yoga and pilates, which have helped me to learn specific vocabulary associated with physical education. Moreover, I insist on writing e-mails in English to my Chinese friends in Canada and even to my cousin, who is currently studying in China. I am finding that how I think and write is changing because I have learned many new words and expressions from my academic advisors, landlady, and university colleagues, as well as friends.

\section{Reflection}

Looking back on my English-learning experiences since I came to Canada, I find that my success has been achieved primarily through actively employing many strategies outside the classroom. I have become an autonomous English-learner while engaging in these out-of-class activities. As Dickinson (1995) says, autonomous language learners are "those who can identify goals, formulate their own goals, and can change goals to suit their own learning needs and interests" (p. 167). I view myself as an autonomous languagelearner because I have taken responsibility for my own learning and decided to set clear goals for enhancing my English communicative competence in a variety of social contexts.

The concept of autonomous language learning has also helped me develop useful language-learning strategies. The origin of learner autonomy in language-learning comes from the Western education movement, which criticizes teacher-centered instruction where students have few opportunities to use language in class. It advocates "the formation of the individual as the core of a democratic society" (Benson \& Voller, 1997, p. 4). As Crabbe (1999) states, "the challenge for the learner autonomy movement is to take greater account of learners' ability to set learning goals and to organize their own learning activity" (p. 3). The key idea of the learner autonomy movement highlights "the exercise of learners' responsibility for their own learning and the right of learners to determine the direction of their own learning" (Benson \& Voller, p. 2). 
In second-language learning, the term autonomous language learning has its root in Holec's (1979) Autonomy and Foreign Language Learning. As Holec (1981) notes, in autonomous language-learning, the learner has the "ability to take charge of one's own learning" (p. 3). It shows "the ideal of learner autonomy with the Western tradition of participatory democracy and the related ideal of self-reliance" (Crabbe, 1999, p. 12). Autonomous language learning enriches the dimension of learners' autonomy in both theoretical and practical language teaching and learning and has been a focus of much research in the field (Cotterall, 1995; Dickinson, 1987, 1995; Hunter \& Cooke, 2007; Hyland, 2004; Lee, 1998; Norton \& Toohey, 2001).

Generally, autonomous language learning focuses on three areas: (a) teacher training programs; (b) counseling learners; and (c) learning strategies of learners. The first two areas emphasize that autonomous language-learning does not mean "learning without teachers out of class" (Snow, 2007, p. 212). Researchers describe how teachers or counselors help or instruct students to learn best through autonomy in formal education programs (Cotterall, 1995; Ho \& Crookall, 1995; Lee, 1998). In this article, however, I emphasize autonomous language-learners' use of self-directed strategies to seek social opportunities to engage in English-learning beyond the classroom (Benson, 2001, p. 62). While learning a language, learners should be capable of organizing and controlling "their own learning objectives, content, techniques, progress, and evaluation" (Holec, 1981, p. 144), thus making learning more effective.

Based on both my understanding of autonomous language-learning and my autonomous English-learning experience as an international graduate student in Canada, I provide the following recommendations that may help other East Asian international graduate students improve their oral competence in English.

\section{Recommendations}

\section{Set Clear Goals and Focus on Personal Interests to Achieve New Needs}

Set clear goals. International graduate students should have a clear goal for learning English if they are to achieve success in their study and life abroad. Norton and Toohey (2001) note that good language-learners should understand "specific local contexts with specific practices" (p. 311). The first and most important goal for international graduate students is to improve their oral English skills while in Canada. They should break oral English-learning into a series of practical tasks to meet the demands of their academic and social lives: themes such as foods, sports, customs, services, hobbies, and cultural practices will help make their life easier and more enjoyable. International graduate students should locate and organize resources that can help support their language-learning experiences and achieve the goals 
that they have set for themselves. According to Snow (2007), when the learning becomes clearer and "more manageable," it will facilitate the effectiveness and confidence of English-learning.

Play to your personal interests. Personal interest also plays an important role in enhancing international graduate students' English study. Individuals have varied hobbies and interests, so they can choose materials or activities that are of interest to them in order to become engaged and improve their English proficiency. For example, I like to volunteer as a teacher in order to share the culture and history of my home country with others. As well, I am interested in fashion, and so I pay more attention to learning vocabulary for clothing and cosmetics when I go shopping. However, I have noticed that most men are interested in sports, current news, and politics. Exploring areas of interest areas will maintain learners' interest and attention, as well as speed the learning process. Similar results were reported by Kodama (2007) and Snow (2007).

\section{Challenge Your Current Circumstances: Choose Appropriate Accommodations}

As a result of my experience studying and living in Canada as an international graduate student, I advise others to challenge themselves in order to improve their English. They can live with either native-English families or other international students who speak other languages and come from other cultural backgrounds. International graduate students spend most of their time in two main places. One is in the university where they concentrate on their academic studies, for example, taking graduate courses, reading articles, doing experiments, and writing papers. There is limited time for them to have conversations with others to improve their oral language. Brown (2008) argues that "international students often reduced their cultural adaptation and social life to the minimum in order to fulfill their role as a student" ( $\mathrm{p}$. 6). The other place is their living accommodation. If international graduate students live with people from other ethnic groups, the opportunity for using English to interact will be greater. English should be the lingua franca that connects everyone. Students must use it to understand others and make themselves understood. Besides, openness to experiencing other languages, cultures, and people helps us develop an understanding of multiculturalism in Canada. As a result, international graduate students can enrich their cognitive knowledge and learn to respect and appreciate other cultures.

\section{Develop an Awareness of Autonomous Language Learning}

I caution international graduate students not to overestimate their English proficiency because of their past successful experience as English-language learners in their home country. We should realize that autonomous Englishlearning is a lifelong process and that it should be conducted according to 
the cultural context. Each cultural context has its own norms for evaluating English teaching and learning. Therefore, developing, sustaining, or reforming autonomous language-learning is particularly significant for international graduate students in adapting to a new language environment. For East Asian students, the issue that challenges us most is social communication skills. Strong oral English skills are essential for us to achieve academic success in Canada. Littlewood (1997) notes, "autonomy is only possible to the extent that students possess both the willingness and ability to act independently" (p. 82). If we can maintain a positive attitude, we will be able to achieve an advanced level of English and enjoy our social life overseas.

I would argue that an autonomous language-learner should also be a critical thinker with the ability to "question the nature of education and a search for alternative forms of knowledge and action" (Pennycook, 1997, p. 40). My English-learning experience in Canada shows that I have been a reflective language-learner. Rather than giving up when I encountered difficulties with my oral English skills, I chose to reflect critically on my earlier English-learning experiences in both China and Canada and to use that knowledge to change my outlook on the situation. I hope that other current international graduates as well as prospective international graduate students will also be critical language-learners. With an awareness of varied social contexts, these students can adjust their learning perspectives and strategies both to study and to life in Canada. In addition, I hope that my experience will provide some insights for university administrators to work more effectively in helping international students who face language challenges.

\section{Recommendation to Academic Institutions: Autonomous Language Learning is not Isolated Learning}

I would point out that autonomous language-learning is not isolated learning. Education systems should recognize the difficult situation in which international graduates find themselves (Spurling, 2006). According to Lave and Wenger (1991), the concepts of community of practice and power relations play an important role in English-learners' access to language-learning opportunities. In the university community, all organizations can play important roles in providing language support programs to prepare international graduate students for successful adaptation to their new academic program and life.

However, I did not feel that I received adequate assistance or support from the university for my English-learning. As Spurling (2007) argues, the university usually sees international graduate students as only "subject learners," but ignores the fact that they are also "culture and language learners" in the community (p. 114). When taking classes, I could talk only to my instructors and classmates in the classroom. I felt lonely after class. Although the university provides orientation for new graduate students every year, I 
felt overwhelmed. There was too much information to remember in such a short time, especially when both the academic and social cultures were so different from mine. My recommendations for universities, international graduates' organizations, and departments are as follows.

First, universities should design required ESL credit courses for international graduate students to improve their English skills. The program should be appropriate for students' proficiency levels and address the language requirements of both academic study and social life. When students' languagelearning and knowledge of Canadian culture improve, they will be more confident and more likely to succeed in their academic studies. Second, international graduate student organizations and university departments should offer both short-term and long-term informal language programs and encourage international graduate students to enroll. For example, language exchanges, volunteering, club activities, and peer programs can provide valuable opportunities for students to associate with people in the community. Moreover, language support program representatives should actively seek students because some may be hesitant or anxious about interacting with English-speakers. Generally, the main goal of university language support programs is to prepare international graduate students for successful adaptation to their new academic program and social life by supporting their English proficiency.

\section{Conclusion}

In sharing my journey of learning English as an autonomous learner, I hope that my experiences and insights will be useful to other international graduate students, especially those from East Asia. Fortunately, a group of international graduates responded positively to my suggestions when we talked about my article. Having had similar learning and living experiences in a foreign country, they agreed with me that language-learning depends very much on personal motivation. International graduate students should take the initiative to leave the "academic ghetto" and work to improve their English in a broader sociocultural context. Accordingly, my peers thought that my recommendations seemed practical.

I stress to international graduate students who study and live in Canada that their oral English skills will not automatically improve unless they become autonomous language-learners and develop new learning strategies. Developing, sustaining, or reforming the practices of autonomous languagelearning is particularly significant in assisting international graduate students to adapt to their new language environment. As Snow (2007) argues, "once students leave formal language programs, it is particularly important that they strategize their language study in ways that take current practical problems into account" (p. 220). International graduate students also need to realize that studying in Canada does not mean that studying is separate 
from social life. Aside from their academic studies, they should go beyond the classroom and gain awareness of autonomous language experiences by accessing more opportunities to experience local cultural and social events. This will improve their English proficiency and assist them in developing an understanding of Canada's multicultural society. Finally, international graduate students should be critical learners as they pursue autonomous language-learning. It is my hope that universities and other postsecondary institutions will begin to focus more on the challenges faced by international graduate students and provide more adequate support for them.

\section{Acknowledgments}

I offer my sincere gratitude to the people who have made the publication of this article possible: my academic advisor Heather Blair for her vital encouragement, continual support, and guidance; Zhou Wu, my instructor, for his helpful comments and critiques of my article; my friends Jie Xiong and Miao Sun for their continual help and encouragement; and most especially my mom, my family members, and my landlady for their continuing love and concern.

\section{The Author}

Lu Liu has a MEd in ESL education from the Faculty of Education, University of Alberta, and graduated from the program in November 2008. She is now working at Harbin Normal University in China and is studying for her doctorate in comparative education (ESL) at the same university.

\section{References}

Bakhtin, M.M. (1981). The dialogic imagination: Four essays. Austin, TX: University of Texas Press.

Benson, P. (2001). Teaching and researching autonomy in language learning. Harlow, UK: Longman.

Benson, P., \& Voller, P. (1997). (Eds.). Autonomy and independence in language learning (pp. 1-12). London: Longman.

Brown, L. (2008). The incidence of study-related stress in international students in the initial stage of the international sojourn. Journal of Studies in International Education, 12, 5-28.

Coates, N. (2004). The "stranger," the "sojourner" and the international student. Proceedings of the Education in a Changing Environment Conference. Available: http://www.ece.salford.ac.uk/proceedings/papers/nc_04.rtf

Coleman, J.A. (1997). State of the art article: Residence abroad within language study. Language Teaching, 30, 1-20.

Cotterall, S. (1995). Readiness for autonomy: Investigating learner beliefs. System, 23, 195-205.

Crabbe, D. (1999). Instruction. In S. Cotterall \& D. Crabbe (Eds.), Learner autonomy in language learning: Defining the field and effecting change (pp. 3-9). Frankfurt am Main: Peter Lang.

Cummins, J. (1984). Bilingualism and special education: Issues in assessment and pedagogy. San Diego, CA: College-Hill Press.

Derwing, T.M., Thomson, R.I., \& Munro, M.J. (2006). English pronunciation and fluency development in Mandarin and Slavic speakers. System, 34, 183-193.

Dickinson, L. (1987). Self-instruction in language learning. Cambridge, UK: Cambridge University Press.

Dickinson, L. (1995). Autonomy and motivation: A literature review. System, 23, 165-174.

Freed, B.F. (1998). An overview of issues and research in language learning in a study abroad setting. Interdisciplinary Journal of Study Abroad, 4, 31-60. 
Gass, S.M., \& Selinker, L. (2008). Second language acquisition: An introductory course (3rd ed.). Mahwah, NJ: Erlbaum.

Ho, J., \& Crookall, D. (1995). Breaking with Chinese cultural traditions: Learner autonomy in English language teaching. System, 23, 235-243.

Holec, H. (1979). Autonomy and foreign language learning. Strasbourg: Council of Europe.

Holec, H. (1981). Autonomy and foreign language learning. Oxford, UK: Pergamon Press.

Hunter, J., \& Cooke, D. (2007). Through autonomy to agency: Giving power to language learners. Prospect, 22, 72-88.

Hyland, F. (2004). Learning autonomously: Contextualising out-of-class English language learning. Language Awareness, 13, 180-202.

Jackson, J. (2002). Reticence in second language case discussions: Anxiety and aspirations. System, 30, 65-84.

Johnson, M. (2004). A philosophy of second language acquisition. New Haven, CT: Yale University Press.

Kodama, Y. (2007). Japanese students' contact with native English speakers during a study abroad experience. Unpublished master's thesis, University of Alberta.

Krashen, S. (1982). Principles and practice in second language acquisition. Oxford, UK: Pergamon Press.

Lave, J., \& Wenger, E. (1991). Situated learning: Legitimate peripheral participation. Cambridge, UK: Cambridge University Press.

Lee, I. (1998). Supporting greater autonomy in language learning. ELT Journal, 52, 282-290.

Littlewood, W. (1997). Self-access: Why do we want it and what can it do? In P. Benson \& P. Voller (Eds.), Autonomy and independence in language learning (pp. 79-91). London: Longman.

Norton, B., \& Toohey, K. (2001). Changing perspectives on good language learners. TESOL Quarterly, 35, 307-322.

Nunan, D. (1991). Language teaching methodology. London: Prentice Hall.

Pennycook, A. (1997). Cultural alternatives and autonomy. In P. Benson \& P. Voller (Eds.), Autonomy and independence in language learning (pp. 35-53). London: Longman.

Perrucci R., \& Hu, H. (1995). Satisfaction with social and educational experiences among international graduate students. Research in Higher Education, 36, 491-508.

Ranta, L. (2007). Measuring language exposure during study abroad. Presentation at the University of Alberta.

Searle, W., \& Ward, C. (1990). Prediction of psychological and sociocultural adjustment during cross-cultural transition. International Journal of Intercultural Relations, 14, 449-464.

Siu, P.C.P. (1952). "The sojourner." American Journal of Sociology, 58, 34-44.

Snow, D. (2007). Sustaining self-directed language learning in the Chinese context. In J. Liu (Ed.), English language teaching in China: New approaches, perspectives and standards (pp. 211232). London: Continuum.

Spurling, N. (2007). Exploring adjustment: The social situation of Chinese students in UK higher education. Learning and Teaching in the Social Sciences, 3, 95-117.

Suh, J.S., Wasanasomsithi, P., Short, S., \& Majid, N.A. (1999). Out-of-class learning experiences and students' perceptions of their impact on conversation skills. ERIC Document Retrieval No. ED433715.

Swain, M., Kinnear, P., \& Steinman, L. (2010). Sociocultural theory in second language education. Bristol, UK: Multilingual Matters.

Toohey, K. (1998). "Breaking them up, taking them away": ESL students in grade 1. TESOL Quarterly, 32, 61-84.

Trice, A.G. (2004). Mixing it up: International graduate students' social interactions with American students. Journal of College Student Development, 45, 671-687.

Umakoshi, T. (1997). Internationalization of Japanese higher education in the 1980's and early 1990's. Higher Education, 34, 259-273. 
Walter, T. (2004). Teaching English language learners: The how-to handbook. White Plains, NY: Longman.

Vygotsky, L.S. (1978). Mind in society: The development of higher psychological processes. Cambridge, MA: Harvard University Press.

Zimmermann, S. (1995). Perceptions of intercultural communication competence and international student adaptation to an American campus. Communication Education, 44, 321-335. 